\title{
THE IMPACT OF INTANGIBLES OF GERMAN, ENGLISH AND PORTUGUESE COMPANIES: FROM 1999 TO 2016
}

\author{
TIAGO VASCONCELOS ${ }^{1}$ \\ (iD) https://orcid.org/0000-0001-6166-0078 \\ DENIS FORTE \\ (iD) https://orcid.org/0000-0002-2933-2039 \\ LEONARDO F. C. BASSO \\ (iD) https://orcid.org/0000-0002-3064-0194
}

To cite this paper: Vasconcelos, T., Forte, D., \& Basso, L. F. C. (2019). The impact of intangibles of German, English and Portuguese companies: From 1999 to 2016. Revista de Administração Mackenzie, 20(4). doi:10.1590/1678-6971/eRAMF190164

Submission: Oct. 29, 2018. Acceptance: Jan. 2, 2019.

\footnotetext{
1 Fundação Instituto de Pesquisas Contábeis, Atuariais e Financeiras (Fipecafi), São Paulo, SP, Brazil.

2 Universidade Presbiteriana Mackenzie (UPM), São Paulo, SP, Brazil.
}

\section{(cc) BY




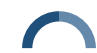

Tiago Vasconcelos, Denis Forte, Leonardo F. C. Basso

\section{ABSTRACT}

Purpose: The present paper is aimed to investigate the relationship between intangible assets, macroeconomic environment and market value of German, English and Portuguese public companies from 1999 to 2016 . Although the IAS 38, assigns value to intangible assets, there is a gap between accounting and the market need. This gap is given by accounting conservatism in the accounting of intangible assets and by their difficult measurement. The verification of the impact of the intangibles on the company's market value is done through the methodology proposed by Gu and Lev (2011), using proxies such as CDS, Libor and Euribor and sensitivity tests. IDE is expected to reflect intangible capital and create shareholder value. This study seeks to interpret the contribution of intangibles and to forecast their impact on the market.

Originality/value: The theme of evaluation of intangible assets has been approached in several ways. Its relevance lies in the need to establish methods for its measurement.

Design/methodology/approach: The methodological approach is quantitative research with panel data using Stata-15. The database is the Capital IQ with public companies, listed in Germany, England, and Portugal from 1999 to 2016, with annual frequency.

Findings: The results suggest that the comprehension value has a positive and significant relationship with the market value of the companies and that the intangible capital and the intangibles-driven-earnings are positively related to research and development expenses and general, administrative procedures.

\section{KEYWORDS}

Intangible assets. Germany. England. Portugal. Sensitivity test. 


\section{INTRODUCTION}

The difference between the economic value of the company and its book value resulted in an increasing concern among analysts and investors, as this divergence was evidenced by the Morgan Stanley (2009) global index, using the value of the listed company of values, is on average double the equity value of the company, and the market value of a company usually ranges from two to nine times its book value.

When it comes to the economic value of a company, Stewart (2003) explains it as the result of the sum of its tangible and intangible assets. According to Jarboe and Ellis (2010), companies can generate results based on their physical and financial assets, and these can be easily bought and sold along with their intangible assets that provide the innovations necessary for the expansion of the company; however these are usually "hidden" in the book value of the company, but it influences the economic valuation of the companies.

Usually, the accounting of human capital and intangibles are the most difficult and complex topics to be measured, and it shows that there have been many points of disagreement when addressing the subject, especially as to how they are to be dealt (Jones \& Chiripanhura, 2010).

However, valuing a company considering its intangible assets is not a simple task, so the International Accounting Standard Board through IAS38, seeks to record the intangible asset closest to the reality of the market. This complexity arises from the difference between the calculation of the market value and the accounting value of a company (Choi, Kwon, \& Lobo, 2000; Demirakos, Strong, \& Walker, 2004; Salamundin et al., 2010).

According to IAS38, intangible assets are only recognized by accounting when the company is sold, and the difference of market value in relation to the book value is determined by recording the customers acquired by the buyer. Jarboe and Ellis (2010) explain that intangible assets are only recorded when events allow for measurement, recording, and disclosure, and it occurs for example when there is a merger or acquisition of companies. Until then, the creation of these assets is left without disclosure, which generates an accumulation not evidenced by the financial statements.

Intangible assets exercise some influence on the value of companies and can modify their capital structure and cash generation capacity, as well as adding value (Damodaran, 2006; Ross, Westerfield, \& Jaffe, 2016). However, the question lies in the relationship between intangible assets, macroeconomic environment and the market value of companies.

During the economic growth in the 1990s, in the midst of the growth of globalization, intensified market competition, and intangible assets were 
the major agents of increased competitiveness among companies, such as technological capital, knowledge, human capital, and capital (Pulido, 2009).

Intangible assets play a macroeconomic key role, as they impact on an economy as a whole and generate growth and cyclical economic trends (Hand \& Lev, 2003). In order to estimate the value of intangible assets that are not recorded in the balance sheet of the company, Gu and Lev (2011) propose a methodology based on the economic concept of "production function", where the value of an intangible asset is estimated by subtracting the normal returns on physical and financial assets.

According to the authors' method, the economic performance of the company is generated by its physical, financial and intangible assets. In order to homogenize the oscillations in the valuation of the physical assets, the average inflation of the period of each country was considered, which was subtracted from the House Price Index of the respective countries of this study, obtaining the proxy of the real percentage of real estate valuation for the calculation of physical assets.

In order to equalize the variations, risks and different types of financial assets, the Euribor average for Germany and Portugal were used as proxy, and the Libor average for England, through the Credit Default Swap (CDS), a proxy to the risk countries. Hull and White (2000) explain that a Credit Swap is a contract that provides insurance against default risk on a given date of a given reference. Credit Swaps are signed with several variables in their composition, in which an important feature is the credit event that represent the occurrence of a "claim" of the ability to pay, and consequently, the inherent risk of each country.

In order to test the different methods of Ebitda weighting and the growth rate of intangible-driven earnings (IDE), sensitivity tests were performed to analyze their impact on the final results of the companies' projections.

Thus, the purpose of this study is to analyze the impact of intangible assets on the creation of publicly traded companies in Germany, England, and Portugal. The structure of this paper is composed as follows: introduction, theoretical framework, methodology, results, and final considerations.

\section{THEORETICAL FRAMEWORK}

\subsection{Intangible assets}

According to the IAS 38, define intangible assets as "[...] an identifiable asset with no physical substance, held for use in the production or supply of goods or services, to be leased to others, or for administrative purposes". 
As for intellectual capital, Liu and Wong (2011) state that it is a set of intangible elements resulting from technological innovations, which generate economic benefit for the company. Investors, while recognizing the importance and values of intangible assets of a company, provide a valuation of the company as a whole, a fact that does not correspond to its book value, especially due to the expectation of generating future benefits (Lev, 2004).

An intangible asset is an identifiable non-monetary and non-physical substance. It is understood that, because they are defined as assets, intangibles are controlled by the entity and provide future economic benefits (IAS38). Intangible assets do not have a physical form and that affect the performance and cash flow of the company (Damodaran, 2006).

\subsection{Market value and value creation}

Rokeach (1973) defines value as a lasting belief in a given model, marketed by pre-existing conduits of a personal or socially accepted character by a group. Authors such as Edvinsson and Malone (1997), Stewart (1999), Sveiby (1997), Lev (2001) and Kaplan and Norton (2004) argue that corporate wealth generation is increasingly related to intangible or intellectual assets.

According to Reilly and Schweihs (2014), knowing the value of intangible assets is important because its valuation establishes a transactional value for purchase and sale; besides the possibility of parameters for planning, credit analysis, and strategic opportunities.

When analyzing the value of a company, it is necessary to separate the concept of intrinsic value from market value. Intrinsic value considers the cash flow that an investor expects to receive in the future (Sharpe, Alexander, \& Bailey, 1999). It is the same concept of discounted cash flow, resulting from the sum of future cash flows, discounted at a rate consistent with their level of risk (Copeland, Koller, \& Murrin, 2000; Damodaran, 2006). In turn, market value can be calculated in some ways. For public companies, the most traditional form is the sum of the market value of the shares with the financial debts at market values, according to Equation 1:

where:

$$
\mathrm{MV}=\mathrm{DM}+\mathrm{SM}
$$

$\mathrm{MV}=$ market value of the company;

$\mathrm{DM}=$ financial debt at market values;

MVS $=$ market value of shares (number of shares $\mathrm{X}$ value of shares). 
Stewart (2003), however, suggests that the market value of a company is the result of the combination of its tangible and intangible assets, according to Equation 2:

$$
\mathrm{MV}=\mathrm{V}_{\mathrm{TA}}+\mathrm{V}_{\mathrm{IA}}
$$

where:

$\mathrm{MV}$ : market value of the company;

$\mathrm{V}_{\mathrm{TA}}$ : value of tangible assets;

$\mathrm{V}_{\mathrm{IA}}$ : value of intangible assets.

According to Young \& O'Byrne (2000), one of the performance evaluation categories is the total shareholder return (TSR), which is only applicable to publicly traded companies and has the advantage of including market expectations about future growth.

\subsection{Classification of the major intangible assets}

As early as 1942, there was concern about the registration of intangible assets, whose major ones were trademarks, contractual rights, design, formulas, customers, licenses, patents, royalties, lawsuits, copyright, names, etc. (Avery, 1942).

\subsubsection{Brands}

According to Kotler and Armstrong (2018), branding is a name, term, symbol or design, or a combination of these elements, which identifies the products or services of a seller and stand them out from their competitors. Kapferer (2015) expands the concept and states it establishes a relationship that leads the product/service, giving meaning and adding values to the consumer.

Theorists have long speculated that the willingness to pay for brands today could depend on past consumer experiences up to six months from the exposure of the brand to the consumer. The disposition by a preference for certain brands is a valuable asset for companies and a source of future economic returns (Bronnenberg, Dubé, \& Gentzkow, 2012).

Brand equity is the most important asset that marketing can contribute to a company, providing price power to a company (Goldfarb, Lu, \& Moorthy, 2009). 


\subsubsection{Patents}

For Nicholas (2013), patents are worldwide central themes for intellectual law. They are an imperfect mechanism for technological development, as well as a formal function of intellectual property protection and an ongoing measure for the level of innovation of a company.

Patents are recognized as a rich source of study, and innovation resources and technological change which provide several advantages in their use (Hall, Jaffe, \& Trajtenberg, 2005).

\subsubsection{Research \& development}

Research and development activities are crucial to increase productivity and transform the economic structure of the company (Nadiri \& Prucha, 2013). It is also associated with the innovation capacity of companies, and this capability refers to innovating in new products, technology, new market strategies, and process improvement, bringing a competitive advantage over their competitors (Surroca, Tribó, \& Waddock, 2010).

Hall et al. (2005) point out that research and development activities conducted by private companies are investment activities, in which companies accumulate a stock of knowledge. If this stock of knowledge contributes positively to the cash flow of the company, it can be observed at its market value.

Hendriksen and Breda (1999) argue that as accounting treatment to be given to research and development expenditures, if it is not possible to anticipate the effect of such expenditures on generating future revenues, such disbursements should be allocated as an expense; if it is possible to identify successful projects capable of generating future revenues, at least direct costs with such projects can be activated to be amortized during periods when such projects are to bring future economic benefit.

\subsubsection{Copyright}

According to Giblin (2017), copyright presents many different objectives, either by contractual law regulation or especially because of the long history of dispute over their ownership. Four objectives are predominantly used to justify the existing terms:

- Encourage initial cultural production.

- Encourage additional cultural production by producing rewards that subsidize investment in new jobs. 


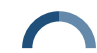

Tiago Vasconcelos, Denis Forte, Leonardo F. C. Basso

- Encourage continuous investments in existing works (that is, ensure their preservation and continuous availability).

- Recognize and reward authors for their creative contributions.

\subsubsection{Franchises and licenses}

According to Kotler and Armstrong (2018), franchises and licenses can be contracted for a definite, indefinite or perpetual time.

The registration of this intangible asset is carried out in the equity account of franchises or licenses only when there are advanced payments of fees and other expenses that are identifiable with the acquisition of the right of operation, which involves the concession and transfer of trademark, technology, operational consulting and products or services.

\subsubsection{Marketing research}

According to Martins (2008), marketing research can refer to pure research, focused on the development of new sciences and technologies, or applied research, focused on the development of products and processes.

In order for the marketing research to be accounted for, the new product development account has certain criteria:

- Technically, these projects are actually given as right.

- Financially, studies show that they are viable.

- The company must have its own or actual assured resources contracted together with third parties to complete the entire development project.

\subsection{Goodwill}

The valuation of a particular asset in relation to its value in which it was acquired in the past is called goodwill (Thulin, 1919). Thus, Winiarsky (2016) notes that the FASB has developed a two-step test to determine whether goodwill is to be carried forward and, if so, by how much. The first step is to compare the fair value of the reporting unit to the book value in the books. If it is at least greater than the book value, goodwill is considered and recorded; however, if it is smaller, it leads to the second step of identifying the fair value of all assets and liabilities, precisely as it would be if some business was acquired.

For Hendriksen and Breda (1999), goodwill is an intangible asset, as well as accounts receivable, prepaid expenses, financial investments and others of easy identification, as opposed to goodwill. 
Goodwill is an intangible asset in the balance sheet and emerges when a company buys another company and integrates their financial statements. After the individual assets and liabilities of the acquired company are added to the balance sheet, goodwill represents the dues that the buyer pays to obtain the business (Tammy, 2017).

In view of the above-mentioned characteristics, goodwill is a complex asset to be defined and measured and therefore recognized in the accounting, except in a purchase and sale transaction, which is reached by the difference between the equity value and the transaction value. For Hendriksen (1991), as a result of the lack of alternative uses, lack of separability and the uncertainty associated with its future economic benefits, goodwill makes accounting recognition questionable.

\subsection{Methods of measurement of intangible assets}

Hovakimian (2006) explains that the book value is the equity value recorded in the accounting reports and in the trade value or market value, which is the stock price of the company in the stock exchange market. The ratio between book value and market value is the so-called market-to-book $(\mathrm{M} / \mathrm{B})$ index.

Rhodes-Kropf and Robinson (2008) claim market-to-book is due to the existence of expectation of future returns of this asset, while according to Luthy (1998), it is possible to distinguish at least four categories of valuation methodology for intangible assets:

- Direct intellectual capital method: the components of intellectual capital are measured directly or by aggregate coefficients.

- Market capitalization method: the difference between the market capitalization and the value of the tangible assets is calculated.

- Return on asset method: uses the ratio between the entity's revenues and the value of the tangible assets.

- Score cards method: the Balanced Score Card methodology is used to evaluate intangible assets.

Stewart (1999) argues that, although confusing, corporate earnings statements do not clearly describe the financial performance of firms, and it is a mistake to mix financial performance measures with intellectual capital, yet we must use them in order to avoid an even worse mistake. 


\subsection{Gu and Lev proposal}

Gu and Lev (2011) propose a method of valuation of intangible assets that is not recorded in the balance sheet of the company due to accounting conservatism and the need of the market in the real valuation of its assets.

The method of valuation of intangible assets has an economic concept of "production function", in which the subtraction of the normal returns in physical and financial assets results in the value of the economic performance of the company.

The economic concept of the production function is a basic principle of economics and is related to the scarcity of available resources, counteracting the needs of men that are unlimited, comprising the physical relationship between the quantities used of a certain set of inputs and quantities (Solow, $1956,1957)$. This formulation is a derivation of the classical theory of growth in economics.

This concept can be applied to a product or service, a company, a sector of activity or even an entire economy. Algebraically, the production function can be presented as follows:

where:

$$
\mathrm{Q}=\mathrm{Q}^{*}(\mathrm{~L}, \mathrm{~K})
$$

$\mathrm{Q}=$ quantity of product produced;

$\mathrm{L}=$ quantity of productive factors of labor;

$\mathrm{K}=$ quantity of productive capital factors.

With the empirical discovery that capital and labor alone are incapable of explaining value creation, there has been a search for factors that could be incorporated into the production function in order to exhaust the factors responsible for value creation. Thus, the intangible factor was incorporated into the model.

It should be emphasized that the discussion begins to be conducted in the most appropriate way to measure the contribution of capital and labor since the contribution of intangibles is the surplus after the deduction of the capital contribution and labor.

Gu and Lev's $(2003,2011)$ proposal is based on an expanded production function, which contained only the factors of production: capital and labor. The expanded production function considers intangibles as a production factor, generating the company's economic performance (EP), composed of physical, financial and intangible assets. The equation proposed is: 


$$
\begin{gathered}
\text { Economic performance }=\alpha * \text { Physical assets }+ \\
\beta^{*} \text { Financial assets }+\delta \text { Intangible assets }
\end{gathered}
$$

where $\alpha, \beta$ and $\delta$ represent the contributions of an asset unit to the company performance.

According to $\mathrm{Gu}$ and Lev (2003, 2011), "intangible-driven earnings" (IDE) is the equation in which economic performance is deducted from the contribution of physical assets and financial assets:

$$
\mathrm{IDE}=\mathrm{EP}-\alpha^{*} \text { Physical assets }-\beta^{*} \text { Financial assets }
$$

Gu and Lev's (2003) methodology is composed of five stages in order to calculate the contribution of the intangible assets by means of the projection of the IDE and the calculation of the inventory of intangible assets.

\subsubsection{Stage 1: Economic performance calculation}

In order to estimate "normalized profits", Gu and Lev (2011) considered the historical average of the last five years as a basis for forecasting future profit, considering $\mathrm{R} \& \mathrm{D}$ and training of employees in order to consider the investments in intangible capital. For the present paper, 13 years of historical average were considered. The calculation of the economic performance (EP) was based on the earnings before interests, taxes, depreciation, and amortization (Ebitda) (Basso, Oliveira, Kimura, \& Braune, 2015).

In this study, data were considered from 1999 on, the same year that the European Common Market adopted the Euro as the official currency of the economic group. In order to measure the sensitivity of the variables impacting the IDE, sensitivity tests were performed on the Ebitda weighting and as a result, an elasticity of $0.85 \%$ was obtained for the calculation of IDE. The same Gu and Lev's Ebtida (2011) of the six subsequent years was used, respectively $4.76 \%, 9.52 \%, 14.29 \%, 19.05 \%, 23.81 \%$, and $28.57 \%$ for each year.

\subsubsection{Stage 2: Calculation of physical and financial assets}

Previous studies have used real estate market data for the calculation of physical assets in the United States (Poterba, 1998); others have considered the factors of production and labor for the calculation of physical assets in 
the USA, Korea and Japan (Nadiri \& Kim, 1996). However, for the present study, the calculation of physical assets considered the house price index (HPI) on the average annual basis of the period by using the Eurostat source, which is the percentage of real estate valuation used in Europe.

In order to neutralize the effects, inflation was subtracted from the average rate of the HPI, obtaining the real percentage of real estate valuation used as the proxy for the calculation of the physical assets.

As a proxy for the calculation of financial assets, Libor and Euribor were used and, as a country risk proxy, it was considered the CDS for each country.

\subsubsection{Stage 3: IDE calculation}

The equation for the calculation of the IDE is:

$$
\mathrm{IDE}=\mathrm{EP}-\mathrm{X} \% \text { * Physical assets }-\mathrm{Y} \% \text { * Financial assets }
$$

The values of $\mathrm{X}$ were considered proxies for the average rentability of the physical assets for Germany, Portugal, and England, respectively $-0.13 \%$, $-0.75 \%$ and $3.85 \%$; and for $\mathrm{Y}$ were considered proxies for the average profitability of the financial assets, respectively $2.33 \%, 2.33 \%$ and $3.54 \%$.

The use of the historical cost of physical assets by means of accounting data rather than replacement cost generates an inclination to substitute for $\mathrm{EP}$ and to overestimate IDE and consequently the intangible assets.

\subsubsection{Stage 4: IDE calculation to three future periods}

In order to estimate future corporate earnings, a series of IDE was projected over three future periods in which different values of economic growth are assumed; in the first period, from one to 13 years; in a second period, from 14 to 18 years, weighted up to a growth of $1.5 \%$ and in the third period, from 19 years to infinity. Subsequently, given the value of economic performance and the values of physical and financial assets of the balance sheets of the company, the value of the intangible assets was derived.

It was calculated the IDE of the company for the three periods. The second period is a projection in which IDE may converge linearly to average growth of $1.5 \%$ and the third period is a projection of steady growth of $1.5 \%$. 


\section{(Figure 2.6.4.1)}

\section{IDE SERIES OF THREE PERIODS AND CALCULATION OF IDES}

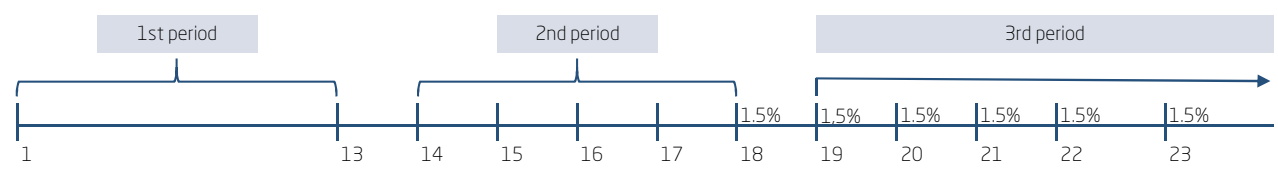

IDE serie calculated in stage 1

IDE series, linearly weighted in $1.5 \%$

IDE series projected with constant annual growth of $1.5 \%$

Source: Elaborated by the authors.

In the present study, complementing the methodology proposed by $\mathrm{Gu}$ and Lev (2011), a sensitivity test was performed in relation to the Growth Rate of companies.

The World Bank and the International Monetary Fund (IMF, 2017) estimate a steady growth rate of $1.5 \%$, so for the sensitivity test, a growth rate of $0.5 \%$ was considered: $1.0 \%, 1.5 \%, 2.0 \%$ and $2.5 \%$.

After performing the sensitivity test of the growth rates for the calculation of the IDE of all companies in this study, according to Figure 2.6.4.2, there was an elasticity of $0.197 \%$ for the Ebitda weighting.

(Figure 2.6.4.2)

SENSITIVITY TEST - GROWTH RATE

\begin{tabular}{cc}
\hline Growth rate & \% IDE growth \\
\hline $0.50 \%$ & $0.00 \%$ \\
\hline $1.00 \%$ & $0.197 \%$ \\
\hline $1.50 \%$ & $0.394 \%$ \\
\hline $2.00 \%$ & $0.591 \%$ \\
\hline $2.50 \%$ & $0.788 \%$ \\
\hline
\end{tabular}

Source: Elaborated by the authors. 


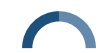

Tiago Vasconcelos, Denis Forte, Leonardo F. C. Basso

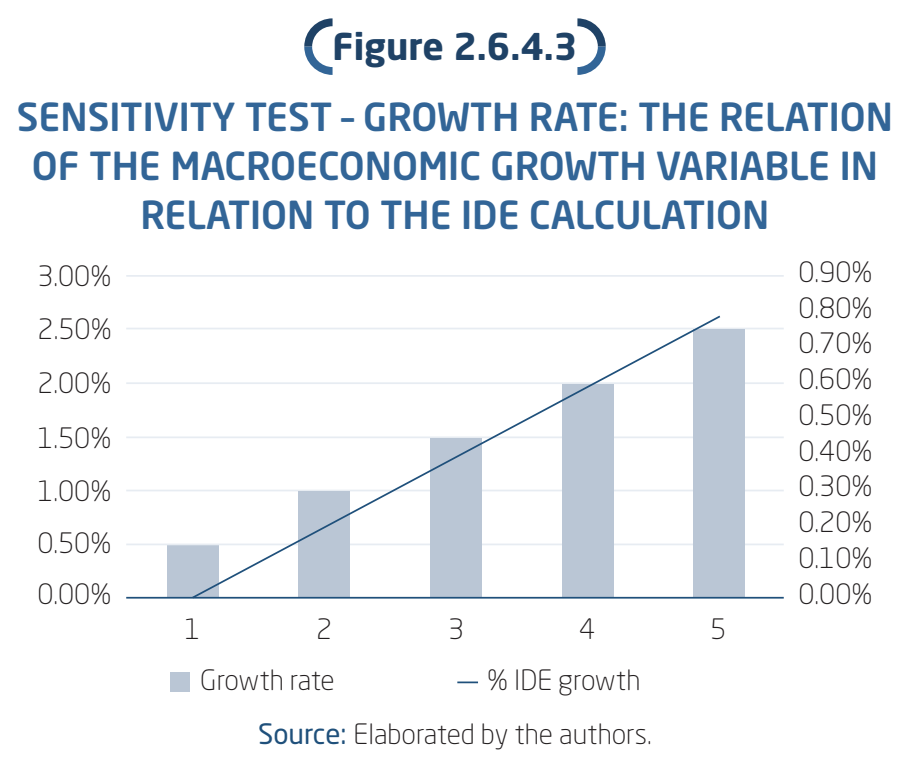

In view of the sensitivity test results, the irrelevance of the impact of the IDE, and a variation of $0.5 \%$ in the growth rate were verified, thus it was considered the $1.5 \%$ growth rate estimated (International Monetary Fund, 2017) for this study.

\subsubsection{Stage 5: Determination of the intangible capital stock}

To obtain the intangible capital stock, it was calculated from the IDEs series the present value of future gains and it's perpetuity by a discounted rate of $1.5 \%$.

\section{METHODOLOGY}

The present quantitative research aims to measure the impact of intangible assets in public companies in Germany, England, and Portugal using the methodology proposed by Gu and Lev (2011). Aiming at improving $\mathrm{Gu}$ and Lev's methodology (2011), the CDS proxies were used to calculate the country risk variable. To calculate the financial assets, it was used the Libor and Euribor as proxies, and the House Price Index for the calculation of fixed assets. In addition it was performed two sensitivity tests: 1 . the Ebitda weighting for the calculation of the IDE and its elasticity calculation of all companies in this study, with a rate of $0.85 \%$ by the use of the Linear 
EBITDA weighting method, this one was proposed by Gu and Lev (2011), and; 2 . growth percentage for the calculation of IDE in the three future periods in a range of growth rate of $0.5 \%, 1.0 \%, 1.5 \%, 2.0 \%$, and $2.5 \%$. It was obtained an elasticity of $0,197 \%$ for each $0.5 \%$ of growth rate, so, for this paper, it was considered the growth estimation forecasted by IMF (2017) of $1.5 \%$.

The database is the Capital IQ and data were obtained from 1999 to 2016; the econometric tests were performed with Stata-15 software.

After the loss of the degree of freedom, due to the delay of 1 period, as well as the disregard of part of the missing database, the final sample of the survey is composed of 519 companies from Germany, 1,151 companies from England and 28 from Portugal.

In order to answer the research problem of this project, the assumptions based on the proposal by Gu and Lev (2011) were used.

- H1: The higher is the investment in research and development (RD), capital expenditure (CAPEX) and sales, general and administrative expenses (SGA), the higher is the intangible-driven-earnings (IDE) of the companies.

$$
\mathrm{IDE}_{i t}=\beta_{o i}+\beta_{1} \mathrm{RD}_{i t-1}+\beta_{2} \mathrm{CAPEX}_{i t-1}+\beta_{3} \mathrm{SGA}_{i t-1}+\varepsilon_{i t-1}
$$

- H2: The higher is the investment in research and development (RD), capital expenditure (CAPEX) and sales, general and administrative expenses (SGA), the higher is the intangible capital (IC) of companies.

$$
\mathrm{IC}_{i t}=\beta_{o i}+\beta_{1} \mathrm{RD}_{i t-1}+\beta_{2} \mathrm{CAPEX}_{i t-1}+\beta_{3} \mathrm{SGA}_{i t-1}+\varepsilon_{i t-1}
$$

- H3: The higher is the degree of intangibility (IDE), the operational performance and its variation (EARN), the higher is the total return to the shareholder (TSR).

$\mathrm{TSR}_{i t}=\beta_{o i}+\beta_{1} \mathrm{IDE}_{i t-1}+\beta_{2} \Delta \mathrm{IDE}_{i t-1}+\beta_{3} \mathrm{EARN}_{i t-1}+\beta_{4} \Delta \mathrm{EARN}_{i t-1}+\varepsilon_{i t-1}$

- H4: The higher is the comprehensive value $(\mathrm{CV})$, the higher is the market value (MV).

$$
\mathrm{MV}_{i t}=\beta_{o i}+\beta_{1} \mathrm{CV}_{i t-1}+\varepsilon_{i t-1}
$$


- H5: The higher is the intangible capital margin (ICM), the higher is the total shareholder return (TSR).

$$
\mathrm{TSR}_{i t}=\beta_{o i}+\beta_{1} \mathrm{ICM}_{i t-1}+\varepsilon_{i t-1}
$$

- H6: The higher is the margin of intangible gain (IDEM), the higher is the total shareholder return (TSR).

$$
\mathrm{TSR}_{i t}=\beta_{o i}+\beta_{1} \mathrm{IDEM}_{i t-1}+\varepsilon_{i t-1}
$$

- H7: The higher is the operational intangible capital margin (ICOM), the higher is the total shareholder return (TSR).

$$
\operatorname{TSR}_{i t}=\beta_{o i}+\beta_{1} \mathrm{ICOM}_{i t-1}+\varepsilon_{i t-1}
$$

- H8: The higher is the ratio between intangible capital and book value (ICBV), the higher is the total shareholder return (TSR).

$$
\mathrm{TSR}_{i t}=\beta_{o i}+\beta_{1} \mathrm{ICBV}_{i t-1}+\varepsilon_{i t-1}
$$

- H9: The higher is the ratio between market value and comprehensive value $(\mathrm{MtCV})$, the higher is the total shareholder return (TSR).

$$
\mathrm{TSR}_{i t}=\beta_{o i}+\beta_{1} \mathrm{MtCV}_{i t-1}+\varepsilon_{i t-1}
$$

- H10: The higher is the return on investment in research and development (RI), the higher is the total shareholder return (TSR).

$$
\mathrm{TSR}_{i t}=\beta_{o i}+\beta_{1} \mathrm{RI}_{i t-1}+\varepsilon_{i t-1}
$$

\subsection{Search variables}

Figure 3.1.1 shows the search variables extracted from the Capital IQ database, as well as their respective acronyms, description, and code in the database. 


\section{(Figure 3.1.1)}

VARIABLES EXTRACTED FROM THE CAPITAL IQ DATABASE

\begin{tabular}{lll}
\multicolumn{1}{c}{ Acronym } & \multicolumn{1}{c}{ Code } & \multicolumn{1}{c}{ Capital IQ } \\
\hline PPE & IQ_NPPE & Property, plant, and equipment \\
\hline FA & IQ_CASH_EQUIV & Cash and equivalents \\
\hline CAPEX & IQ_CAPEX & Capital expenditure \\
\hline DPS & IQ_TOTAL_DIV_PAID_CF & Dividends per share \\
\hline EBITDA & IQ_EBITDA & Earnings before interest, taxes, \\
\hline OP & IQ_OPER_INC & depreciation, and amortization \\
\hline EQ & IQ_TOTAL_EQUITY & Operating income \\
\hline LSP & IQ_LASTSALEPRICE & Equity \\
\hline SO & IQ_SHARESOUTSTANDING & Market price - year end \\
\hline RD & IQ_RD_EXP & Stock number \\
\hline SGA & IQ_SGA & Research and development \\
\hline TA & IQ_TOTAL_ASSETS & Selling, general, and administrative \\
\hline TL & IQ_TOTAL_LIAB_EQUITY & Total assets \\
\hline REV & IQ_TOTAL_REV & Total liabilities \\
\hline & & Revenue \\
\hline
\end{tabular}

Source: Elaborated by the authors.

\subsection{Construction of variables}

According to Figure 3.2.1, for this work, the variables of the database were considered for the purpose of analyzing the intangibility of companies (Basso et al., 2015). 


\section{(Figure 3.2.1)}

\section{DATABASE VARIABLES}

\begin{tabular}{|c|c|c|}
\hline Variable & Variable description & Variable calculation \\
\hline PPE & Properties, plants, and equipment & Extracted capital IQ \\
\hline Cash & Represents cash and cash equivalents & Extracted capital IQ \\
\hline Ebitda & $\begin{array}{l}\text { Earnings before interests, taxes, depreciation, and } \\
\text { amortization }\end{array}$ & Extracted capital IQQ \\
\hline R\&D & Research and development expenses & Extracted capital IQ \\
\hline CAPEX & $\begin{array}{l}\text { Capital expenditure: represents expenses with } \\
\text { acquisition and investment in fixed assets }\end{array}$ & Extracted capital IQ \\
\hline CV & $\begin{array}{l}\text { Comprehensive value: value related to the difference in } \\
\text { value of tangible and intangible assets between book } \\
\text { value and market value }\end{array}$ & $C V=I C+$ book value \\
\hline MV & Market value of shares & $M V=Q A * P F A$ \\
\hline EARN & EBITDA variation & EARN $=$ Ebitda $n-$ Ebitda $n-1$ \\
\hline IDE & $\begin{array}{l}\text { Intangible drive earnings: a variable defined by Gu and } \\
\text { Lev }(2003,2011) \text { for measuring the degree of } \\
\text { intangibility of the company. The variable is based on } \\
\text { the economic performance of the company, on the } \\
\text { physical and financial assets. }\end{array}$ & $\begin{array}{l}\text { IDE }=E P-\alpha \text { * Physical assets - } \\
\beta^{*} \text { Financial assets }\end{array}$ \\
\hline IC & $\begin{array}{l}\text { Intangible capital: intangible capital calculated by Gu } \\
\text { and Lev }(2003,2011)\end{array}$ & $\mathrm{IC}=$ present value of the IDE series \\
\hline SGA & $\begin{array}{l}\text { Selling, general and administrative expenses: represents } \\
\text { the expenses not attributed to the production process, } \\
\text { but related to sales and general and administrative } \\
\text { expenses }\end{array}$ & Extracted capital IQ \\
\hline TSR & $\begin{array}{l}\text { Total shareholder return: represents the financial value } \\
\text { created for the shareholder over time }\end{array}$ & $\begin{array}{l}\text { TSR }=((\text { final share price }- \text { initial share } \\
\text { price }) / \text { initial share price })+ \text { dividends. Share } \\
\text { price and dividends }\end{array}$ \\
\hline ICM & $\begin{array}{l}\text { Intangible capital margin: index of intangibility created } \\
\text { by Lev (1999) and Gu and Lev (2003) }\end{array}$ & $I C M=I C /$ sales \\
\hline ICOM & $\begin{array}{l}\text { Intangible capital operating margin: index of } \\
\text { intangibility created by Lev (1999) and Gu and Lev } \\
\text { (2003) }\end{array}$ & ICOM = IDE/operating income \\
\hline $\mathrm{Rl}$ & $\begin{array}{l}\text { Return on investment of R\&D: an index of intangibility } \\
\text { created by Lev (1999) and Gu and Lev (2003) }\end{array}$ & $\mathrm{RI}=\mid \mathrm{C} / \mathrm{R} \& \mathrm{D}$ \\
\hline $\mathrm{MtCV}$ & $\begin{array}{l}\text { Market to comprehensive value: approximate value and } \\
\text { indicator of the importance of the intangible and the } \\
\text { proximity of the indicator to the market value. Index of } \\
\text { intangibility created by Lev (1999) and Gu and Lev } \\
\text { (2003) }\end{array}$ & MtCV = Market value/IC \\
\hline
\end{tabular}




\section{(Figure 3.2.1 (conclusion))}

\section{DATABASE VARIABLES}

\begin{tabular}{lll}
\hline Variable & \multicolumn{1}{c}{ Variable description } & \multicolumn{1}{c}{ Variable calculation } \\
\hline ICBV & $\begin{array}{l}\text { Intangible capital to book value: indicate how much of } \\
\text { the company is based on intangible assets. Index of } \\
\text { intangibility created by Lev (1999) and Gu and Lev } \\
\text { (2003) }\end{array}$ & ICVB = IC/Look value \\
\hline IDEM & $\begin{array}{l}\text { Intangible gain capital margin: margin of intangible } \\
\text { gains. Index of intangibility created by Lev (1999) and } \\
\text { Guand Lev (2003) }\end{array}$ & IDEM = IDE/sales \\
\hline
\end{tabular}

Source: Elaborated by the authors.

\section{RESULTS}

As results obtained from the econometric tests, we have the descriptive statistics according to Figure 4.1, the correlation matrix of the companies according to Figure 4.2 and the summary of results according to Figure 4.3.

As a result of a panel with unbalanced data, and as a stationary data assumption in order not to lose a degree of freedom, the Unitary Root Test was not considered, so there are different numbers of companies in the independent variables.

Figure 4.1 represents the descriptive statistics of Germany, England, and Portugal.

(Figure 4.1)

DESCRIPTIVE STATISTICS

\begin{tabular}{|c|c|c|c|c|c|c|c|c|}
\hline & Hypothesis & Variable & Obs. & Mean & $\begin{array}{c}\text { Std. } \\
\text { deviation }\end{array}$ & Min. & Max. & $\begin{array}{c}\text { No. of } \\
\text { companies }\end{array}$ \\
\hline \multirow{8}{*}{ 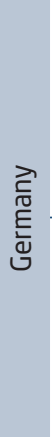 } & \multirow{4}{*}{1} & IDE & 7019 & 521.49 & 2207.34 & -1260.50 & 26838.65 & 523 \\
\hline & & $\mathrm{RD}$ & 1571 & 313.00 & 965.53 & -12.23 & 7660.44 & 135 \\
\hline & & CAPEX & 6427 & 296.24 & 1596.87 & -64.20 & 33276.47 & 507 \\
\hline & & SGA & 6296 & 663.04 & 2517.48 & -16.01 & 34480.48 & 507 \\
\hline & \multirow{4}{*}{2} & IC & 7019 & 35462.72 & 150074.80 & -85735.44 & 1816082.00 & 523 \\
\hline & & $\mathrm{RD}$ & 1571 & 313.00 & 965.53 & -12.23 & 7660.44 & 135 \\
\hline & & CAPEX & 6427 & 296.24 & 1596.87 & -64.20 & 33276.47 & 507 \\
\hline & & SGA & 6296 & 663.04 & 2517.48 & -16.01 & 34480.48 & 507 \\
\hline
\end{tabular}




\section{(Figure 4.1 (continuation)) \\ DESCRIPTIVE STATISTICS}

\begin{tabular}{|c|c|c|c|c|c|c|c|c|}
\hline & Hypothesis & Variable & Obs. & Mean & $\begin{array}{c}\text { Std. } \\
\text { deviation }\end{array}$ & Min. & Max. & $\begin{array}{c}\text { No. of } \\
\text { companies }\end{array}$ \\
\hline \multirow{17}{*}{ 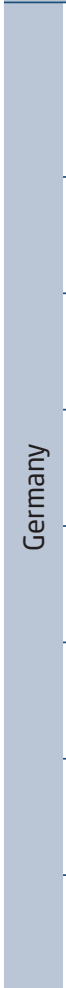 } & \multirow{3}{*}{3} & TSR & 5760 & 2.58 & 15.11 & -1.00 & 409.76 & 468 \\
\hline & & IDE & 7019 & 521.49 & 2207.34 & -1260.50 & 26838.65 & 523 \\
\hline & & EARN & 6932 & 477.84 & 2094.10 & -14679.54 & 28192.05 & 520 \\
\hline & \multirow{2}{*}{4} & MV & 5842 & 3109.92 & 11614.20 & -74266.55 & 159947.90 & 489 \\
\hline & & CV & 7019 & 40885.02 & 173247.30 & 0.17 & 2248608.00 & 523 \\
\hline & \multirow{2}{*}{5} & TSR & 5760 & 2.58 & 15.11 & -1.00 & 409.76 & 468 \\
\hline & & ICM & 7016 & -484.78 & 33435.95 & -2792747.00 & 52337.75 & 523 \\
\hline & \multirow{2}{*}{6} & TSR & 5760 & 2.58 & 15.11 & -1.00 & 409.76 & 468 \\
\hline & & IDEM & 7016 & -7.13 & 491.59 & -41059.49 & 769.02 & 523 \\
\hline & \multirow{2}{*}{7} & TSR & 5760 & 2.58 & 15.11 & -1.00 & 409.76 & 468 \\
\hline & & ICOM & 7016 & 1.42 & 19.89 & -523.10 & 779.43 & 523 \\
\hline & \multirow{2}{*}{8} & TSR & 5760 & 2.58 & 15.11 & -1.00 & 409.76 & 468 \\
\hline & & ICVB & 6939 & 7.05 & 23.07 & -209.65 & 904.54 & 523 \\
\hline & \multirow{2}{*}{9} & TSR & 5760 & 2.58 & 15.11 & -1.00 & 409.76 & 468 \\
\hline & & MtCV & 5830 & 0.10 & 2.37 & -78.38 & 92.30 & 489 \\
\hline & \multirow{2}{*}{10} & TSR & 5760 & 2.58 & 15.11 & -1.00 & 409.76 & 468 \\
\hline & & $\mathrm{Rl}$ & 1571 & 523.84 & 4839.78 & -86166.98 & 114209.10 & 135 \\
\hline \multirow{11}{*}{$\begin{array}{l}\text { 므 } \\
\frac{\pi}{00} \\
\text { ज़ }\end{array}$} & \multirow{4}{*}{1} & IDE & 13114 & 335.01 & 2049.15 & -606.87 & 45383.58 & 1162 \\
\hline & & $\mathrm{RD}$ & 1536 & 88.76 & 465.28 & -7.14 & 5679.00 & 219 \\
\hline & & CAPEX & 12351 & 169.37 & 1298.07 & -380.14 & 39975.00 & 1141 \\
\hline & & SGA & 12402 & 292.77 & 1368.01 & -859.96 & 22668.88 & 1149 \\
\hline & \multirow{4}{*}{2} & IC & 13114 & 21888.21 & 133342.00 & -41064.83 & 2912966.00 & 1162 \\
\hline & & $\mathrm{RD}$ & 1536 & 88.76 & 465.28 & -7.14 & 5679.00 & 219 \\
\hline & & CAPEX & 12351 & 169.37 & 1298.07 & -380.14 & 39975.00 & 1141 \\
\hline & & SGA & 12402 & 292.77 & 1368.01 & -859.96 & 22668.88 & 1149 \\
\hline & \multirow{3}{*}{3} & TSR & 11307 & 9.50 & 59.94 & -1.00 & 2986.83 & 1094 \\
\hline & & IDE & 13114 & 335.01 & 2049.15 & -606.87 & 45383.58 & 1162 \\
\hline & & EARN & 12877 & 371.86 & 2355.73 & -1050.40 & 55794.00 & 1150 \\
\hline
\end{tabular}




\section{(Figure 4.1 (continuation)) \\ DESCRIPTIVE STATISTICS}

\begin{tabular}{|c|c|c|c|c|c|c|c|c|}
\hline & Hypothesis & Variable & Obs. & Mean & $\begin{array}{c}\text { Std. } \\
\text { deviation }\end{array}$ & Min. & Max. & $\begin{array}{c}\text { No. of } \\
\text { companies }\end{array}$ \\
\hline \multirow{14}{*}{ 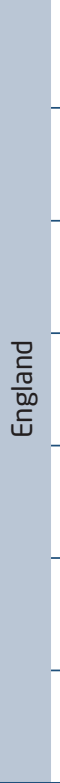 } & \multirow{2}{*}{4} & MV & 11554 & 2718.00 & 14212.01 & -38606.83 & 3120172.00 & 1128 \\
\hline & & CV & 13114 & 24733.68 & 147925.20 & 0.00 & 262352.80 & 1162 \\
\hline & \multirow{2}{*}{5} & TSR & 11307 & 9.50 & 59.94 & -1.00 & 2986.83 & 1094 \\
\hline & & ICM & 12199 & -556.64 & 92842.28 & -8338425.00 & 5869139.00 & 1098 \\
\hline & \multirow{2}{*}{6} & TSR & 11307 & 9.50 & 59.94 & -1.00 & 2986.83 & 1094 \\
\hline & & IDEM & 12199 & -8.42 & 1372.77 & -123228.00 & 86736.04 & 1098 \\
\hline & \multirow{2}{*}{7} & TSR & 11307 & 9.50 & 59.94 & -1.00 & 2986.83 & 1094 \\
\hline & & ICOM & 13113 & 0.61 & 58.41 & -4895.19 & 1061.64 & 1161 \\
\hline & \multirow{2}{*}{8} & TSR & 11307 & 9.50 & 59.94 & -1.00 & 2986.83 & 1094 \\
\hline & & ICVB & 13034 & -11.22 & 1252.29 & -138270.50 & 21685.10 & 1162 \\
\hline & \multirow{2}{*}{9} & TSR & 11307 & 9.50 & 59.94 & -1.00 & 2986.83 & 1094 \\
\hline & & $\mathrm{MtCV}$ & 11572 & -0.09 & 11.70 & -558.85 & 682.68 & 1129 \\
\hline & \multirow{2}{*}{10} & TSR & 11307 & 9.50 & 59.94 & -1.00 & 2986.83 & 1094 \\
\hline & & $\mathrm{RI}$ & 1536 & 235.13 & 9878.03 & -292937.80 & 70312.31 & 219 \\
\hline \multirow{15}{*}{ 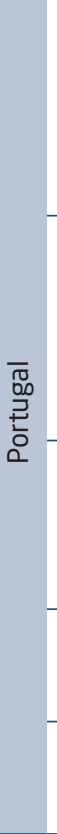 } & \multirow{4}{*}{1} & IDE & 481 & 321.47 & 678.02 & -79.29 & 4813.58 & 28 \\
\hline & & $\mathrm{RD}$ & 397 & 31.87 & 49.40 & 0.12 & 277.24 & 28 \\
\hline & & CAPEX & 405 & 185.94 & 413.21 & -0.12 & 4897.93 & 28 \\
\hline & & SGA & 397 & 281.93 & 472.89 & 0.12 & 2772.40 & 28 \\
\hline & \multirow{4}{*}{2} & IC & 481 & 19071.97 & 43406.56 & -3637.92 & 291191.60 & 28 \\
\hline & & $\mathrm{RD}$ & 397 & 31.87 & 49.40 & 0.12 & 277.24 & 28 \\
\hline & & CAPEX & 405 & 185.94 & 413.21 & -0.12 & 4897.93 & 28 \\
\hline & & SGA & 397 & 281.93 & 472.89 & 0.12 & 2772.40 & 28 \\
\hline & \multirow{3}{*}{3} & TSR & 397 & 18.58 & 43.03 & -0.99 & 345.34 & 28 \\
\hline & & IDE & 481 & 321.47 & 678.02 & -79.29 & 4813.58 & 28 \\
\hline & & EARN & 431 & 326.07 & 682.71 & -51.37 & 4776.99 & 28 \\
\hline & \multirow{2}{*}{4} & MV & 481 & 18876.67 & 44604.45 & -4999.42 & 362358.20 & 28 \\
\hline & & CV & 389 & 1590.21 & 3261.25 & 1.67 & 23356.74 & 28 \\
\hline & \multirow{2}{*}{5} & TSR & 397 & 18.58 & 43.03 & -0.99 & 345.34 & 28 \\
\hline & & ICM & 433 & 9.89 & 12.01 & -43.28 & 64.60 & 28 \\
\hline
\end{tabular}




\section{(Figure 4.1 (conclusion))}

\section{DESCRIPTIVE STATISTICS}

\begin{tabular}{|c|c|c|c|c|c|c|c|c|}
\hline & Hypothesis & Variable & Obs. & Mean & $\begin{array}{c}\text { Std. } \\
\text { deviation }\end{array}$ & Min. & Max. & $\begin{array}{c}\text { No. of } \\
\text { companies }\end{array}$ \\
\hline \multirow{10}{*}{$\begin{array}{l}\bar{c} \\
\stackrel{0}{0} \\
\sum^{\circ} \\
0 \\
0\end{array}$} & \multirow{2}{*}{6} & TSR & 397 & 18.58 & 43.03 & -0.99 & 345.34 & 28 \\
\hline & & IDEM & 433 & 0.35 & 0.30 & -0.75 & 1.00 & 28 \\
\hline & \multirow{2}{*}{7} & TSR & 397 & 18.58 & 43.03 & -0.99 & 345.34 & 28 \\
\hline & & ICOM & 435 & -0.25 & 44.91 & -918.39 & 81.62 & 28 \\
\hline & \multirow{2}{*}{8} & TSR & 397 & 18.58 & 43.03 & -0.99 & 345.34 & 28 \\
\hline & & ICVB & 433 & 6.09 & 5.60 & -12.34 & 38.77 & 28 \\
\hline & \multirow{2}{*}{9} & TSR & 397 & 18.58 & 43.03 & -0.99 & 345.34 & 28 \\
\hline & & $\mathrm{MtCV}$ & 389 & 0.39 & 0.33 & -1.60 & 1.00 & 28 \\
\hline & \multirow{2}{*}{10} & TSR & 397 & 18.58 & 43.03 & -0.99 & 345.34 & 28 \\
\hline & & $\mathrm{RI}$ & 397 & 1589.71 & 7278.56 & -19733.94 & 126844.50 & 28 \\
\hline
\end{tabular}

The database is composed of all public companies in Germany, England, and Portugal available in Capital IQ, regardless of sector and size, thus a high standard deviation of the variables can be verified.

Due to the presence of Ebitda with negative values in the database, there are values for the dependent variables and negative independent variables, reflecting losses over the time for part of the companies in the study period.

Figure 4.2 represents the hypothesis's correlation matrix.

\section{(Figure 4.2)}

\section{HYPOTHESIS'S CORRELATION MATRIX}

\begin{tabular}{|c|c|c|c|c|c|c|c|c|c|c|c|c|}
\hline \multirow[b]{2}{*}{ Hypothesis 1} & \multicolumn{4}{|c|}{ Germany } & \multicolumn{4}{|c|}{ England } & \multicolumn{4}{|c|}{ Portugal } \\
\hline & IDE & $\mathrm{RD}$ & CAPEX & SGA & IDE & $\mathrm{RD}$ & CAPEX & SGA & IDE & $\mathrm{RD}$ & CAPEX & SGA \\
\hline IDE & 1.000 & & & & 1.000 & & & & 1.000 & & & \\
\hline $\mathrm{RD}$ & 0.873 & 1.000 & & & 0.377 & 1.000 & & & 0.490 & 1.000 & & \\
\hline CAPEX & 0.652 & 0.682 & 1.000 & & 0.772 & 0.225 & 1.000 & & 0.438 & 0.366 & 1.000 & \\
\hline SGA & 0.904 & 0.924 & 0.646 & 1.000 & 0.825 & 0.563 & 0.811 & 1.000 & 0.490 & 0.922 & 0.378 & 1.000 \\
\hline
\end{tabular}




\section{(Figure 4.2 (conclusion))}

\section{HYPOTHESIS'S CORRELATION MATRIX}

\begin{tabular}{|c|c|c|c|c|c|c|c|c|c|c|c|}
\hline \multirow[b]{2}{*}{ Hypothesis 2} & \multicolumn{4}{|c|}{ Germany } & \multicolumn{4}{|c|}{ England } & \multicolumn{3}{|c|}{ Portugal } \\
\hline & IC & $\mathrm{RD}$ & CAPEX & SGA & IC & $\mathrm{RD}$ & CAPEX & SGA & IC & $\mathrm{RD}$ & CAPEX SGA \\
\hline IC & 1.000 & & & & 1.000 & & & & 1.000 & & \\
\hline $\mathrm{RD}$ & 0.873 & 1.000 & & & 0.380 & 1.000 & & & 0.466 & 1.000 & \\
\hline CAPEX & 0.653 & 0.682 & 1.000 & & 0.781 & 0.225 & 1.000 & & 0.496 & 0.366 & 1.000 \\
\hline SGA & 0.904 & 0.924 & 0.646 & 1.000 & 0.832 & 0.563 & 0.811 & 1.000 & 0.410 & 0.922 & 0.3781 .000 \\
\hline Hypothesis 3 & TSR & IDE & EARN & & TSR & IDE & EARN & & TSR & IDE & EARN \\
\hline TSR & 1.000 & & & & 1.000 & & & & 1.000 & & \\
\hline IDE & 0.609 & 1.000 & & & 0.581 & 1.000 & & & 0.518 & 1.000 & \\
\hline EARN & 0.643 & 0.907 & 1.000 & & 0.662 & 0.883 & 1.000 & & 0.568 & 0.598 & 1.000 \\
\hline Hypothesis 4 & MV & CV & & & MV & CV & & & MV & CV & \\
\hline MV & 1.000 & & & & 1.000 & & & & 1.000 & & \\
\hline CV & 0.846 & 1.000 & & & 0.933 & 1.000 & & & 0.586 & 1.000 & \\
\hline Hypothesis 5 & TSR & ICM & & & TSR & ICM & & & TSR & ICM & \\
\hline TSR & 1.000 & & & & 1.000 & & & & 1.000 & & \\
\hline ICM & 0.003 & 1.000 & & & 0.007 & 1.000 & & & 0.139 & 1.000 & \\
\hline Hypothesis 6 & TSR & IDEM & & & TSR & IDEM & & & TSR & IDEM & \\
\hline TSR & 1.000 & & & & 1.000 & & & & 1.000 & & \\
\hline IDEM & 0.017 & 1.000 & & & 0.007 & 1.000 & & & 0.036 & 1.000 & \\
\hline Hypothesis 7 & TSR & ICOM & & & TSR & ICOM & & & TSR & ICOM & \\
\hline TSR & 1.000 & & & & 1.000 & & & & 1.000 & & \\
\hline ICOM & 0.017 & 1.000 & & & 0.007 & 1.000 & & & 0.036 & 1.000 & \\
\hline Hypothesis 8 & TSR & ICVB & & & TSR & ICVB & & & TSR & ICVB & \\
\hline TSR & 1.000 & & & & 1.000 & & & & 1.000 & & \\
\hline ICVB & 0.023 & 1.000 & & & 0.006 & 1.000 & & & 0.188 & 1.000 & \\
\hline Hypothesis 9 & TSR & $\mathrm{MtCV}$ & & & TSR & $\mathrm{MtCV}$ & & & TSR & $\mathrm{MtCV}$ & \\
\hline TSR & 1.000 & & & & 1.000 & & & & 1.000 & & \\
\hline $\mathrm{MtCV}$ & 0.023 & 1.000 & & & 0.001 & 1.000 & & & 0.110 & 1.000 & \\
\hline Hypothesis 10 & TSR & $\mathrm{RI}$ & & & TSR & $\mathrm{RI}$ & & & TSR & $\mathrm{RI}$ & \\
\hline TSR & 1.000 & & & & 1.000 & & & & 1.000 & & \\
\hline $\mathrm{Rl}$ & -0.070 & 1.000 & & & 0.131 & 1.000 & & & 0.043 & 1.000 & \\
\hline
\end{tabular}

Source: Elaborated by the authors.

Figure 4.3 shows the hypothesis' results. 


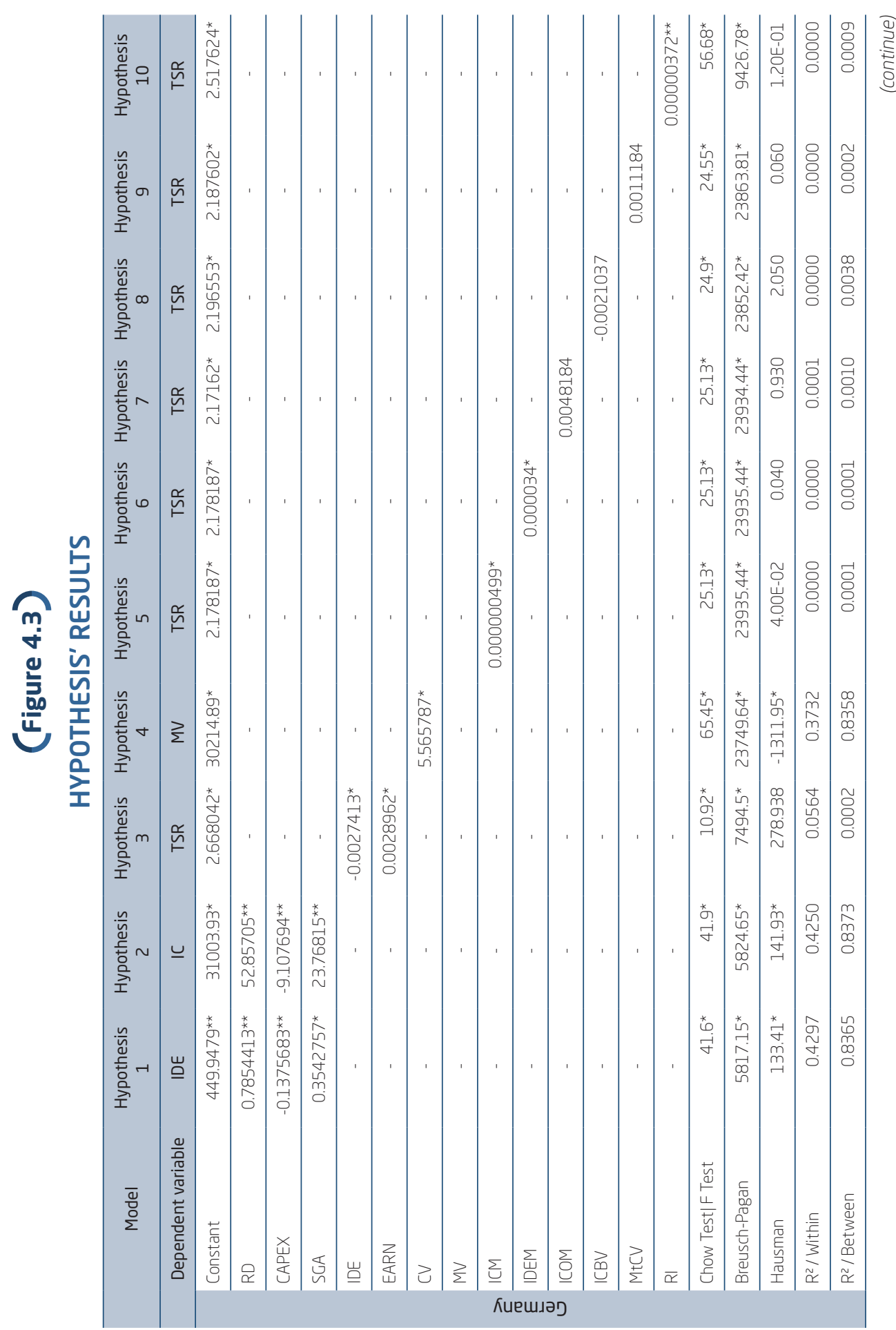




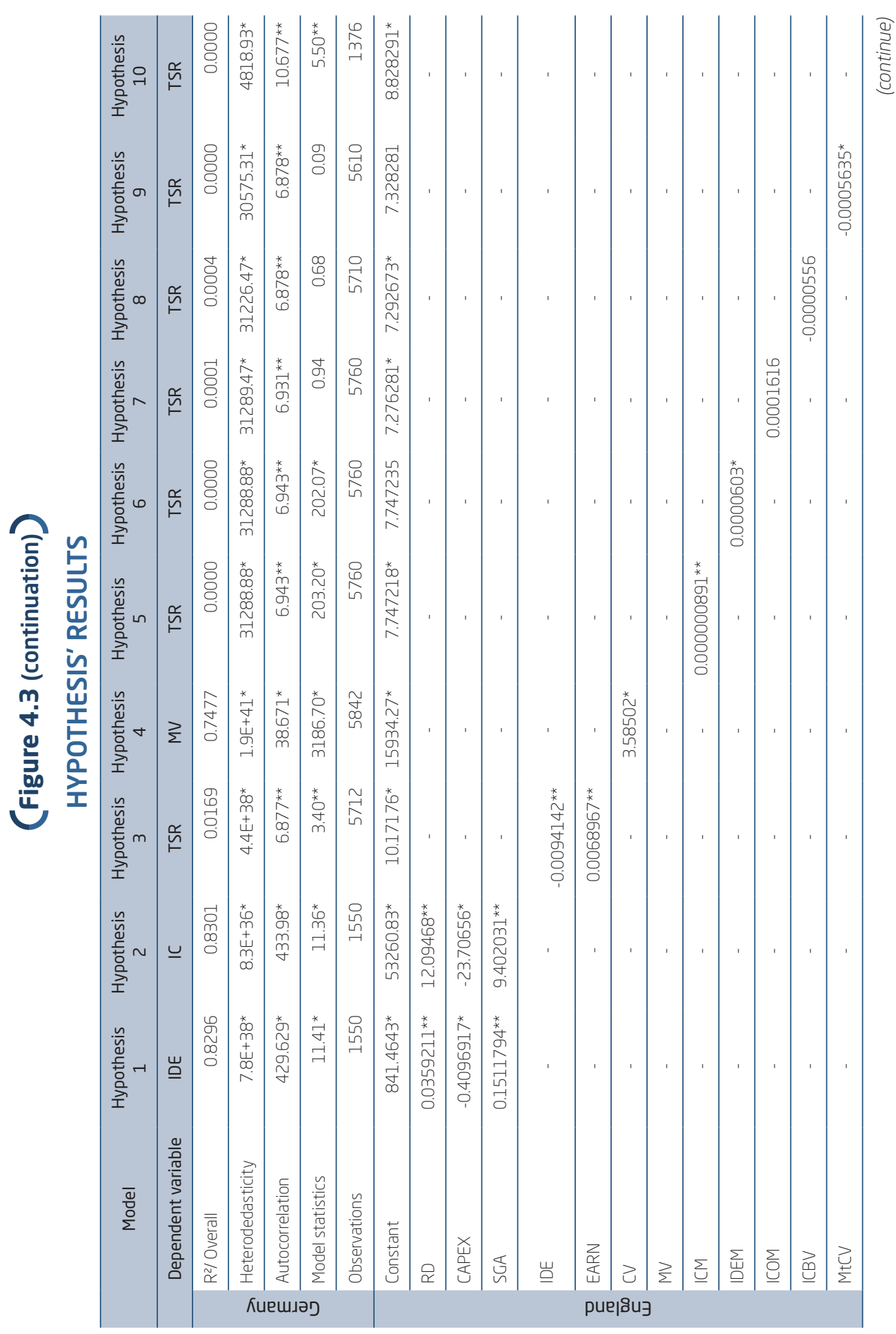




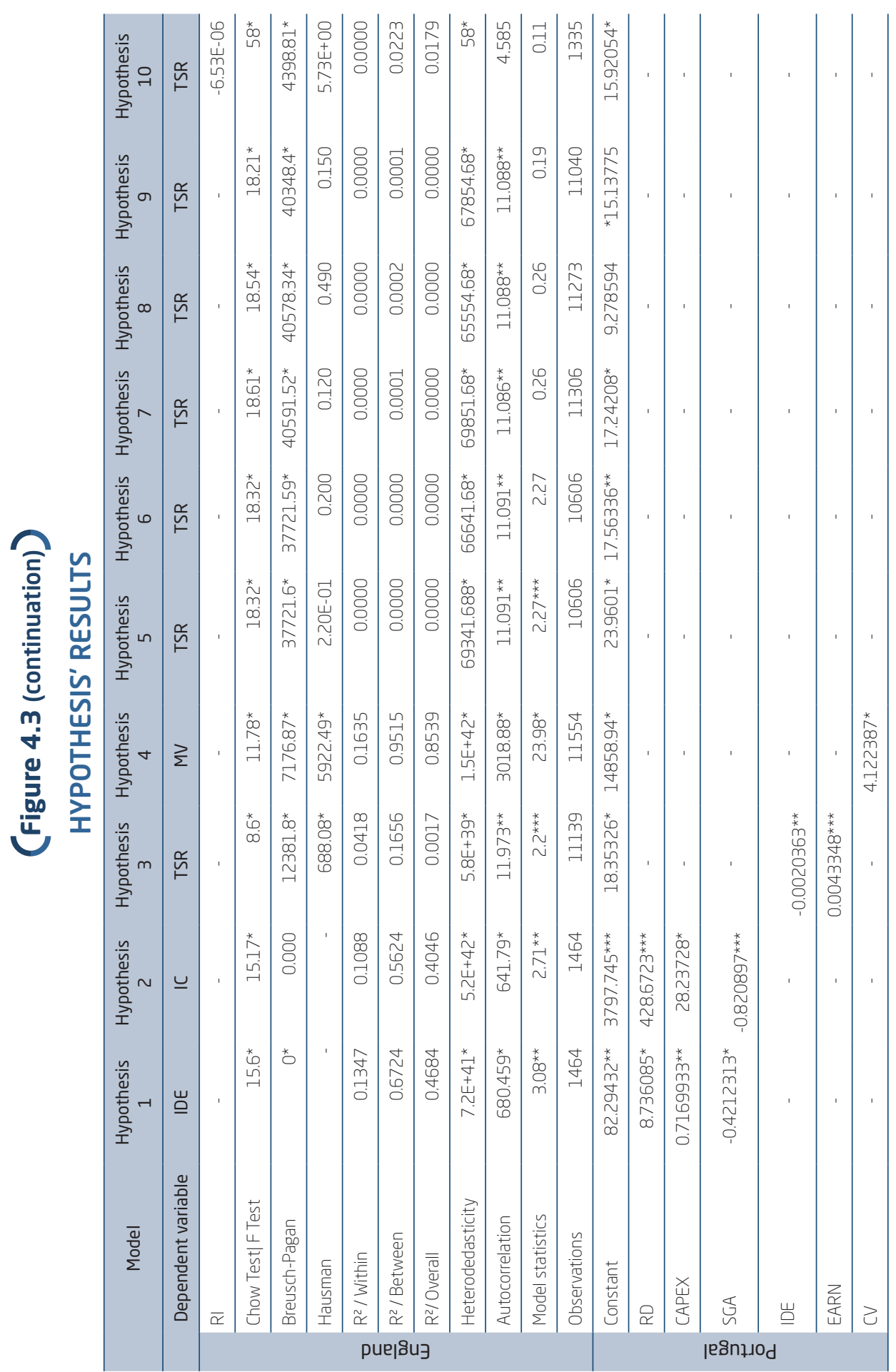




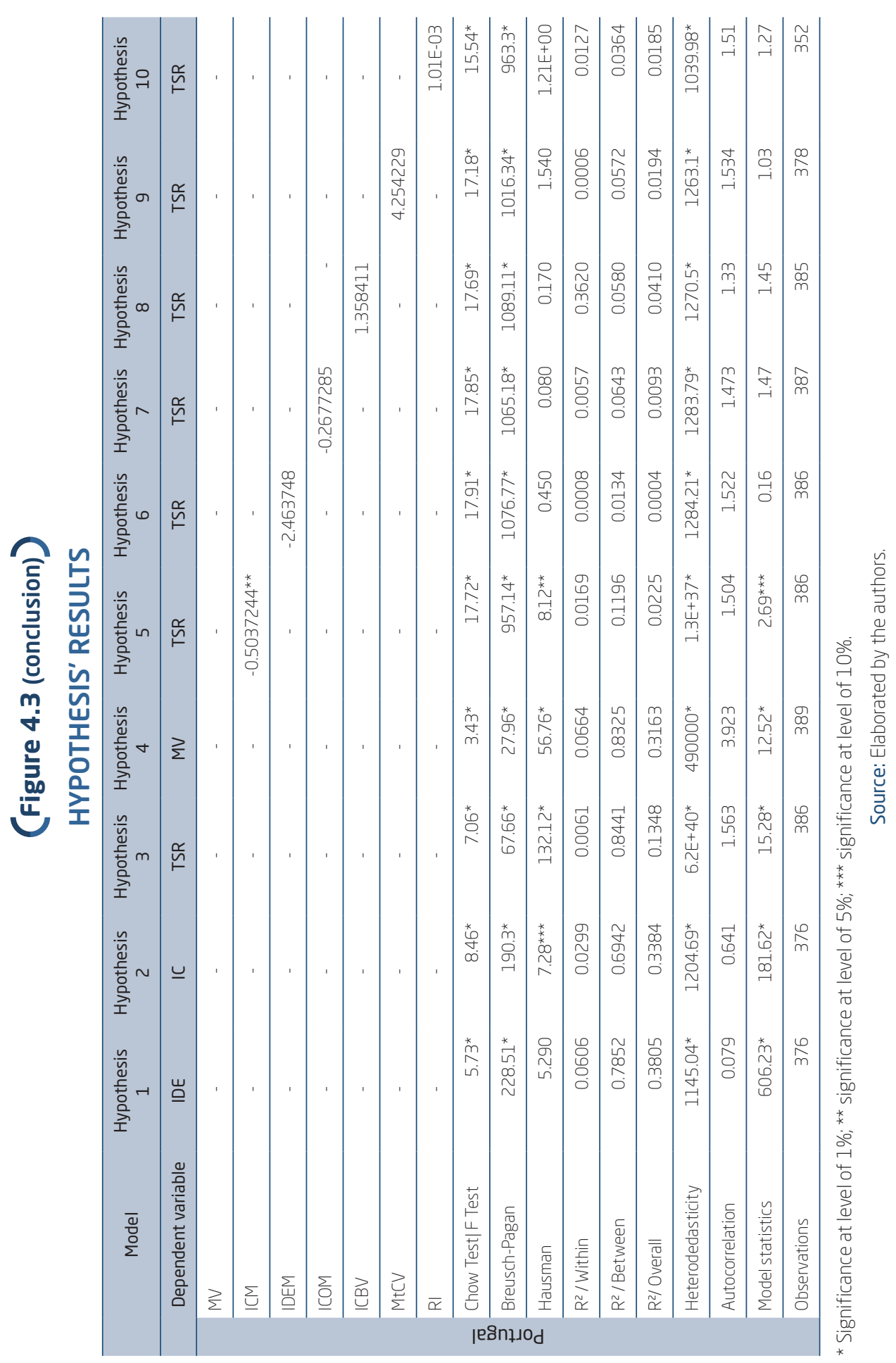


In hypothesis 1 and 2, respectively, IDE and IC were highly correlated with SGA and RD; and in hypothesis $4 \mathrm{MV}$, with CV. For all hypotheses, the following tests were carried out: 1 . Chow test or F test was performed in order to verify the best model between the polled and the fixed effects model; after the 2. LM Breuch-Pays Test, in order to verify which the best model between polled and the random effects model; 3. Hausman test, in order to verify the best model between fixed effects and random effects; 4. Wald test indicating the presence of heteroscedasticity; and 5. Wooldridge test indicating the presence of correlated data.

In the first hypothesis, it is shown that the higher is the investment in research and development $(\mathrm{R} \& \mathrm{D})$, the capital expenditure on tangible assets (CAPEX) and general and administrative expenses (SGA), the higher is the Intangible Drive Earnings (IDE) hypothesis not rejected for Germany and England with a level of significance of $1 \%$. For Portugal, the hypothesis did not present any significance; and the independent variables from Germany and England explained the IDE respectively at $75.13 \%$ and $93.83 \%$, showing evidence that they may be consistent measures for the measurement of intangibles.

The second hypothesis was to demonstrate that the higher is the investment in research and development $(R \& D)$, the capital expenditures in tangible assets (CAPEX) and in general and administrative expenses (SGA), the higher is the intangible capital (IC) in Germany, England, and Portugal with a level of significance of $1 \%$. The independent variables explained the IDE by $75.16 \%$, in relation to the financial measures for the measurement of investments in intangible assets: $93.06 \%$ and $73.28 \%$, showing evidence that the variables of hypothesis 2 can be consistent measures for the measurement of intangible assets.

The third hypothesis shows that the higher is the comprehensive value $(\mathrm{CV})$, the higher is the total shareholder return (TSR), a hypothesis not rejected for Germany with a significance level of 5\%, for England, with a significance of $10 \%$ and for Portugal the hypothesis presented a level of significance of $1 \%$; the independent variables explained the independent variable, respectively, in $53.79 \%, 37.23 \%$ and $81.27 \%$, showing evidence that may be consistent measures for the measurement of intangibles.

In the fourth hypothesis, it was demonstrated that the higher is the comprehension value $(\mathrm{CV})$, the higher is the market value of the company $(\mathrm{MV})$, so that they would be related to the financial measures for the measurement of investments in intangibles; a hypothesis not rejected for Germany, England and Portugal with a significance level of 5\%, 1\% and 5\%, 
respectively. For Germany, England, and Portugal the independent variables explained the MV respectively in $82.13 \%, 94.76 \%$ and $86.82 \%$, showing evidence that they may be consistent measures for the measurement of intangibles.

The fifth hypothesis demonstrates that the higher is the intangible capital margin (ICM), the higher is the total shareholder return (TSR), so that they would be related to the financial measures for the measurement of investments in intangibles. This hypothesis was not rejected for Germany, England, and Portugal, with a significance level of $1 \%, 5 \%$ and 10 , respectively; the independent variables explained the MV by $0.01 \%, 0.01 \%$ and $11.86 \%$, and although they showed significant use of the model, the independent variables presented a low explanatory power of the dependent variable, thus showing weak evidence that they can be consistent measures for the measurement of intangibles.

In the sixth hypothesis, it was tried to demonstrate that the higher is the intangible gain capital margin (IDEM), the higher is the total shareholder return (TSR), so that they would be related to the financial measures for the measurement of investments in intangibles, where $\mathrm{HO}$ was not rejected for Germany and Portugal, and the models were not significant, and for England with a significance level of $5 \%$. For England, the independent variables explained the IDEM by $0.01 \%$

The seventh hypothesis demonstrates that the higher is the intangible capital operating margin (ICOM), the higher is the total shareholder return (TSR), a hypothesis in which $\mathrm{HO}$ was not rejected for the companies of Germany, England, and Portugal, and the models did not present significance, showing evidence that they are not consistent measures for the measurement of intangibles.

In the eighth hypothesis, it was tried to demonstrate that the higher is the intangible capital to book value (ICVB), the higher is the total shareholder return (TSR), a hypothesis in which $\mathrm{H} 0$ was not rejected for the companies of Germany, England, and Portugal. These models did not present significance, showing evidence that they are not consistent measures for the measurement of intangibles.

In the ninth hypothesis, it was tried to demonstrate that the higher is the market to comprehensive value $(\mathrm{MtCV})$, the higher is the total shareholder return (TSR), a hypothesis in which $\mathrm{HO}$ was not rejected for the companies of Germany, England and Portugal, with the models not presenting significance, showing evidence that they are not consistent measures for the measurement of intangibles. 
In the tenth hypothesis, it was tried to demonstrate that the higher is the return on investment of $R \& D(R I)$, the higher is the total shareholder return (TSR), a hypothesis in which $\mathrm{HO}$ was rejected for the companies of Germany with a level of significance of $1 \%$ for the companies of England and Portugal. The model did not present significance, therefore not rejecting $\mathrm{HO}$. For companies in Germany, the independent variables explained the dependent variable by $0.12 \%$, showing evidence that they are not consistent measures for the measurement of intangibles.

\section{FINAL CONSIDERATIONS}

The subject of evaluation of the intangible assets and the impact on the market value of the company has been assessed in the studies of the financial areas in several ways. Its relevance lies in the need to establish methods and tools to measure the value of these assets in a market where they are traded frequently.

In order to carry out this research, 10 hypotheses were tested using the panel data model and samples extracted from the Capital IQ database of public companies from Germany, Portugal, and England from 1999 to 2016. The risk of each country was measured by the CDS proxy, as well as sensitivity tests were performed in the Ebitda weighting by the method proposed by $\mathrm{Gu}$ and Lev (2011) and by the linear weighting method in 6 years; and the growth rate of the economy in $0.5 \%, 1.0 \%, 1.5 \%, 2.0 \%$, and $2.5 \%$; and in that for both tests the sensitivity results did not present relevant levels of variance. The lag of 1 period in the independent variables was performed in relation to the dependent variable.

The present study is aimed to analyze the impact of intangible assets in public companies in Germany, England, and Portugal according to the model proposed by Gu and Lev (2011). A sample was composed of 519 companies from Germany, 1,151 companies from England and 28 companies from Portugal, whose data were obtained from the Capital IQ database in the period from 1999 to 2016. These companies were analyzed by a regression model with panel data.

In the first and the second hypothesis, CAPEX presented a negative correlation with the dependent variable, suggesting that the investment in physical assets contributes negatively to the generation of intangible assets because CAPEX investment generates tangible assets, that is, the opposite of intangible assets in a creation value to one company. 
In the third hypothesis, it was tried to test if the higher is the comprehensive value (CV), the higher is the return to the shareholder (TSR). The results of hypothesis 3 showed that there is a positive and significant relationship in EARN; and the models presented a significance level of $5 \%$ for Germany, of $10 \%$ for England and 1\% for Portugal. Although the results suggest that IDE has a negative effect on shareholder returns, the models used can be measured to measure the intangibility of firms. It means that the higher the Ebitda variation, the higher the intangible capital that reflects in a higher TSR; this represents that the Ebitda is a good measure to create value to the shareholder and it is constantly monitored by the board companies.

In the fourth hypothesis, it was tried to test if the higher is the comprehensive value $(\mathrm{CV})$, the higher is the company's market value (MV). The results showed that there is a positive and significant relationship in $\mathrm{CV}$, and the models presented a level of significance of $1 \%$ for Germany, England, and Portugal, suggesting that they are good measures to the intangibility of companies. It means that's the higher the difference of the intangible capital, that's the present value of IDE's series, and the book value, the higher is the amount related to the intangible assets not booked because of the accounting rules, but the market adds value to these factors regardless the books, generating a higher MV.

In the fifth hypothesis, it was tested if the higher is the intangible capital margin (ICM), the higher is the return to the shareholder (TSR). The results of this hypothesis suggest that the ICM is positively related and significant with TSR for Germany and England, and negatively related to Portugal; ICM is significant in the use of the model at the level of $1 \%$ for Germany and $10 \%$ for England and Portugal, suggesting that they are good measures to measure the intangibility of companies. It means that the higher is the sales, the higher will be the Ebitda, the higher it will be the IC and, consequently, the higher it will be the ICM. Portugal presented a negative relation because it has high collinearity, that usually the statistics invert the signal of the results of the tests.

In the sixth to the tenth hypothesis, the results of the estimated coefficients were not statistically significant, except for the sixth and tenth hypothesis of Germany.

In the sixth hypothesis, it was tried to test if the higher is the intangible gain capital margin (IDEM), the higher is the return to the shareholder (TSR). The results of this hypothesis suggest that the IDEM is positively related and significant with TSR and has significance in the use of the model at the $1 \%$ level for Germany. It means that higher is the sales, the higher will 
be the Ebitda, the higher it will be the IC, the higher will be the IDE and, consequently, the higher will be the IDEM.

In the tenth hypothesis, it was tested if the higher is the return on investment in research and development (IR), the higher the return to shareholders (TSR). The results of this hypothesis suggest that the IR is positively related and significant with TSR and has a significance in the use of the model at the level of $5 \%$ for Germany. It means that by the research and development activities, the company generates market competitive vantage in relation to the competitors, that impact in additional gains, generating a higher Ebitda and a higher TSR.

By means of the Ebitda's sensitivity test, it was observed that there is a small variation in the total value of the IDEs of each country, because of the effects' reflection of cumulative intangible capital over the years; it was also considered the lag of one period in the independent variables in relation to the dependent variable, in order to reflect the effects of the variable actions over the years.

A GDP growth sensitivity test performance was provided in order to study the IDE performance of firms and its sensitivity in the intangible value creation, suggesting that the increase or decrease of a macroeconomic environment directly impacts the results and the intangibility of the companies.

From the results of the ten hypotheses of this study for each of the three countries, it was verified that the hypotheses one to five suggest that most of the intangibility indexes have a positive and significant relation with the market value of the company. However, the results of assumptions 6 to 10 need to be re-evaluated in relation to shareholder value creation, and additional studies are needed to reach a conclusion on these indicators.

According to Basso et al. (2015), studies with the United States service sector showed results similar to those obtained in this study.

Through this paper, as lessons learned, there is a need for a more depth study by sector, establishing dummy by sector: industry, commerce and service; and the dismemberment of hypothesis 3 and more of a hypothesis in order to have a more precise analysis.

The theme of intangible assets has been a challenge for companies and the market, both in its accounting aspect in its recognition and measurement and in the financial in its valuation and creation of value to the market and shareholders. Thus, this paper was not intended to be an end or to cover every aspect of the issue, but to be a midpoint and aim at a better understanding. As a suggestion of improvement and future studies: 1. segment companies by sector; 2. segment companies by size of billing; 3 . segment companies between tangible-intensive and intangible-intensive; 4 . studies with other 
countries; and 5. use of other value measures such as net income, changes in research and development investment, and marketing, training and other income statement intangible capital.

\section{O IMPACTO DE INTANGÍVEIS DE EMPRESAS ALEMÃS, INGLESAS E PORTUGUESAS: DE 1999 A 2016}

\section{RESUMO}

Objetivo: O presente artigo tem o propósito de investigar qual é a relação entre intangíveis, ambiente macroeconômico e valor de mercado das empresas abertas alemãs, inglesas e portuguesas no período 1999 a 2016. Apesar de o IAS 38 atribuir valor aos ativos intangíveis, há uma grande lacuna entre a contabilização e a necessidade do mercado. Essa lacuna é dada pelo conservadorismo contábil na contabilização dos ativos intangíveis e por sua difícil mensuração. A verificação do impacto dos intangíveis no valor de mercado da empresa é feita por meio da metodologia proposta por Gu e Lev (2011), utilizando proxies como CDS, Libor e Euribor e testes de sensibilidade. Espera-se que o IDE reflita o capital intangível e crie valor ao acionista. Este estudo busca interpretar a contribuição dos intangíveis e a previsão de seu impacto no mercado.

Originalidade/valor: $\mathrm{O}$ tema de avaliação dos ativos intangíveis tem sido abordado de diversas formas. Sua relevância está na necessidade de estabelecer métodos para sua mensuração.

Design/metodologia/abordagem: A abordagem metodológica é uma pesquisa quantitativa com dados em painel com a utilização do Stata-15. A base de dados é o Capital IQ com empresas de capital aberto, listadas na Alemanha, na Inglaterra e em Portugal de 1999 a 2016, com frequência anual.

Resultados: Os resultados sugerem que o comprehension value tem uma relação positiva e significante com o valor de mercado das empresas, e que o intangible capital e o intangibles-driven-earnings são positivamente relacionados com os gastos de pesquisa e desenvolvimento e gastos de vendas, gerais e administrativos.

\section{PALAVRAS-CHAVE}

Ativos intangíveis. Alemanha. Inglaterra. Portugal. Teste de sensibilidade. 


\section{REFERENCES}

Avery, H. G. (1942). Accounting for intangibles. The Accounting Review, 17, 354-363. Retrieved from https://www.jstorn.org

Basso, L. F., Oliveira, J. A. S., Kimura, H., \& Braune, E. S. (2015). The impact of intangibles on value creation: Comparative analysis of the $\mathrm{Gu}$ and Lev methodology for the United States software and hardware sector. Investigaciones Europeas de Dirección y Economía de la Empresa, 21 (2), 73-83. Retrieved from http://www.sciencedirect.com/science/article/pii/ S1135252314000392

Bronnenberg, B. J., Dubé, J. P., \& Gentzkow, M. (2012). The evolution of brand preferences: Evidence from consumer migration. The American Economic Review, 12(6), 2472-2508. Retrieved from https://www.jstorn.org

Choi, W. W., Kwon, S. S., \& Lobo, G. J. (2000). Market valuation of intangible assets. Journal of Business Research, 49, 35-45. Retrieved from http://www. sciencedirect.com/science/article/pii/S0148296398001210

Copeland, T., Koller, T., \& Murrin, J. (2000). Valuation: Measuring and managing the values of companies (3rd ed.) . New York: McKinsey \& Company.

Damodaran, A. (2006). Damodaran on valuation: Security analysis for Investment and corporate finance (3rd ed.). New Jersey: John Wiley \& Sons.

Demirakos, E. G., Storng, N. C., \& Walker, M. (2004). What valuation models do analysts use? Accounting Horizons, 18(4), 221-240. Retrieved from http://aaajournals.org/doi/abs/10.2308/acch.2004.18.4.221 ?code= aaan-site

Edvinsson, L., \& Malone, M. S. (1997). Intellectual capital: Realizing your company's true value by finding its hidden brainpower. New York: Harper Collins Publishers.

Giblin, R. (2017). Reimagining copyright's duration. Retrieved from https:// papers.ssrn.com/sol3/papers.cfm?abstract_id $=2561108$

Goldfarb, A., Lu, Q., \& Moorthy, S. (2009). Measuring brand value in an equilibrium framework. Marketing Science, 28(1), 69-86. Retrieved from https://www.jtorn.org

$\mathrm{Gu}, \mathrm{F}$, , \& Lev, B. (2003). Intangible assets-measurement, drivers, usefulness. Recuparado de http://www.stern.nyu.edu/ blev/.

$\mathrm{Gu}, \mathrm{F}$, \& Lev, B. (2011). Intangible assets-measurement, drivers, usefulness. In G. Schiuma (Ed.). Managing knowledge assets and business value creation in organizations: Measures and dynamics (pp. 110-124). New York: IGI Global Snippet. Retrieved from https://www.igiglobal.com/chapter/intangible assetsmeasurementdriversusefulness $/ 50252$ 
Hall, B., Jaffe, A., \& Trajtenberg, M. (2005). Market value and patent citations. The Rand Journal of Economics, 36(1),16-38. Retrieved from https://www.jstron.org

Hand, J. R. M., \& Lev, B. (2003). Intangible assets. New York: Oxford University. Hendriksen, E. S., \& Breda, M. F. V. (1991). Accounting theory. New York: Irwin Professional Publishing.

Hendriksen, E. S., \& Breda, M. F. V. (1999). Teoria da contabilidade. (2nd ed.). (Antônio Zaratto Sanvicente, Transl.). São Paulo: Atlas.

Hovakimian, A. (2006). Are observed capital structures determined by equity market timing?. The Journal of Financial and Quantitative Analysis, 41 (1), 221-243. Retrieved from https://www.jstron.org

Hull, J., \& White, A. (2000). Valuing credit default swaps: No counterparty default risk. Journal of Derivatives, 8(1), 29-40. Retrieved from http://www. gfigroup.com/portal/pdfs/CredDefSw1.pdf

International Accounting Standard (2001). IAS 38 - Intangible assets. Retrieved from https://www.ias.org

International Monetary Fund (2017). World economic and financial survey: World Economic outlook. Retrieved from https://www.imf.org/external/ pubs/ft/weo/2017/01/weodata/index.aspx

Jarboe, K. P., \& Ellis, I. (2010). Intangible assets: Innovative financing for innovation. Issues in Science and Technology, 26(2), 75-80. Retrieved from http://issues.org/26-2/jarboe-2/

Jones, R., \& Chiripanhura, B. (2010). Measuring the UK's human capital stock. Economic \& Labour Market Review, 36-63. Retrieved from https:// www.ons.gov.uk

Kapferer, J. N. (2015). How luxury brands can grow yet remain rare. Philadelphia: Kogan Page.

Kaplan, R. S., \& Norton, D. P. (2004). Strategy maps: Converting intangible assets into tangible outcomes. Boston: Harvard Business School Press.

Kotler, P., \& Armstrong, G. (2018). Principles of marketing (17th ed.). Harlow: Pearson Education.

Lev, B. (2001). Intangibles: Management, measurement, and reporting. Washington: Brookings.

Lev, B. (2004). Sharpening the intangibles edge. Harvard Business Review, June, 109-116. Retrieved from http://raw.rutgers.edu/docs/intangibles/ Papers/Sharpening\%20the\%20Intangibles\%20Edge.pdf 
Liu, Q., \& Wong, K. P. (2011). Intellectual capital and financing decisions: Evidence from the US patent data. Management Science, 57(10), 1861-1878. Retrieved from http://pubsonline.informs.org/doi/abs/10.1287/mnsc. 1110.1380? journalCode $=$ mnsc

Luthy, D. H. (1998). Intellectual capital and its measurement. Retrieved from http://citeseerx.ist.psu.edu/viewdoc/download?doi=10.1.1.200.5655\&re $\mathrm{p}=$ rep $1 \&$ type $=\mathrm{df}$

Martins, E (2008). Palestra virtual sobre a nova lei das S/A e a internacionalização da contabilidade. Retrieved from https://slideplayer.com.br/slide/3423021/

Martins, E., Schmidt, P., Santos, J. L., \& Marins, S. P. (2017). Avaliação de empresas. São Paulo: Atlas.

Morgan Stanley. 2009. Global Economic Forum. Retrieved from http://www. morganstanley.com/views/gef/index.html

Nadiri, M. I., \& Kim, S. (1996). R\&D, production structure and productivity growth: A comparison of the US, Japanese and Korean manufacturing sectors. National Bureau of Economic Research, 1-29. January 2006. Retrieved from https://www.researchgate.net/publication/5193481_RD_Production_ Structure_and_Productivity_Growth_A_Comparison_of_the_US_Japanese_ and_Korean_Manufacturing_Sectors

Nadiri, M. I., \& Prucha, I. R. (2013). Estimation of the depreciation rate of physical and R\&D capital in the US. Total manufacturing sector. Economy Inquiry, 34, 43-56. Retrieved from http://onlinelibrary.wiley.com/doi/10. 1111/j.1465-7295.1996.tb01363.x/full

Nicholas, T. (2013). Hybrid innovation in Meji, Japan. International Economic Review, 54(2), 575-600. Retrieved from https://www.jstorn.org

Poterba, J. M. (1998). The rate of return to corporate capital and factor shares: New estimates using revised national income accounts and capital stock data. Cambridge: National Bureau of Economic Research (pp. 211-246). Retrieved from http://www.nber.org/papers/w6263

Pulido, A. (2009). Una comparativa internacional en la mediación del capital intangible de países. Revista de Economia Mundial, 23, 245-261. Retrieved from https://www.redalyc.org

Reilly, R. F., \& Schweihs, R. P. (2014). Valuing intangible assets (2nd ed.). New York: McGraw-Hill.

Rhodes-Kropf, M., \& Robinson, D. T. (2008). The Market for mergers and the boundaries of the firm. The Journal of Finance, 63 (3), 1169-1211. Retrieved from http://citeseerx.ist.psu.edu/viewdoc/download?doi=10.1. 1.582.3462\&rep $=$ rep $1 \&$ type $=$ pdf 
Rokeach, M. (1973). The nature of human values. New York: The Free Press.

Ross, S. A., Westerfield, R. W., \& Jaffe, J. F. (2016). Corporate finance (11th ed.). New York: McGraw-Hill.

Salamundin, N., Bakar, R., Ibrahim, M. K., \& Hassan, F.H. (2010). Intangible assets valuation in the Malaysian capital market. Journal of Intellectual Capital, 11(3), 391-405. Retrieved from http://www.emeraldinsight.com/ doi/abs/10.1108/14691931011064608

Sharpe, W. F., Alexander, G. J., \& Bailey, J. V. (1999). Investments (6th ed.). New Jersey: Prentice Hall.

Solow, R. (1956). A contribution to the theory of economic growth. Quarterly Journal of Economics, 70(1), 65-94.

Solow, R. (1957). Technical change and the aggregate production function. Review of Economic Studies, 39, 321-330.

Stewart, T. A. (1999). Intellectual capital the new wealth of organizations. New York: Doubleday.

Stewart, T. A. (2003). The wealth of knowledge: Intellectual capital and the twentyfirst century organization. New York: Doubleday.

Surroca, J., Tribó, J. A., \& Waddock, S. (2010). Corporate responsibility and financial performance: The role of intangible resources. Strategic Management Journal, 31(5), 463-490. Retrieved from http://dx.doi.org/10.1002/ smj. 820

Sveiby, K. E. (1997). The new organizational wealth: Managing and measuring. San Francisco: Berret-Koehler.

Tammy, W. (2017). FASB kills bundersome goodwill impairment test. Compliance Week, Jan 2017. Retrieved from https://www.complianceweek. com/fasb-kills-burdensome-goodwill-impairment-test/9978.article

Thulin, F. (1919). Goodwill and others nondepreciable and depreciable intangible property as "invested capital". Michigan Law Review, 17(4), 294-309. Retrieved from https://www.jstorn.org

Winiarsky, M. (2016). FASB looks to cut out second step of goodwill accounting. Compliance Week, 13(150), 54-56. Retrieved from https:// www.complianceweek.com/news/news-article/fasb-looks-to-cut-outthat-\%E2\%80\%98second-step\%E2\%80\%99-of-goodwill-accounting\#. WdDCS ltSzIU

Young, D., O’Byrne, S. F. (2000). EVA® and Value-Based-Management. New York: McGraw Hill. 


\section{AUTHOR NOTES}

Tiago Vasconcelos, Centro de Ciências Sociais e Aplicadas (CCSA), Universidade Presbiteriana Mackenzie (UPM); Denis Forte, Centro de Ciências Sociais e Aplicadas (CCSA), Universidade Presbiteriana Mackenzie (UPM); Leonardo F. C. Basso, Economics, New School for Social Research.

Tiago Vasconcelos is now professor at Programa de Pós-Graduação em Contabilidade, Controladoria e Finanças (Cefin) at Fundação Instituto de Pesquisas Contábeis, Atuariais e Financeiras (Fipecafi); Denis Forte is now professor at Centro de Ciências Sociais e Aplicadas (CCSA) at Universidade Presbiteriana Mackenzie (UPM); Leonardo F. C. Basso is now professor at Centro de Ciências Sociais e Aplicadas (CCSA) at Universidade Presbiteriana Mackenzie (UPM).

Correspondence concerning this article should be addressed to Tiago Vasconcelos, Rua Professor Rodolfo São Tiago, 157, 162C, Belém, São Paulo, SP, Brazil, CEP: 03059-050.

E-mail: tiagodevasconcelos@yahoo.com.br

\section{EDITORIAL BOARD}

Editors-in-chief

Janette Brunstein

Silvia Marcia Russi de Domênico

Associated Editor

Silvio Popadiuk

Technical Support

Vitória Batista Santos Silva

\section{EDITORIAL PRODUCTION}

Publishing Coordination

Jéssica Dametta

Language Editor

Daniel de Almeida Leão

\author{
Layout Designer \\ Emap
}

Graphic Designer

Libro 